Trevithick's Locomotives", a paper on "The Invention of Roller Drawing in Cotton Spinning" by the late Mr. A Seymour-Jones, and the presidential address of Mr. Titley, who dealt with the aims of the Society and the ways to achieve them.

From the first, membership of the Society has been open to all irrespective of nationality or sex, and the earliest published list contains names of members in the United States, Germany, Switzerland and China. In its second year the Society adopted an emblem, a griffin, looking backward yet going forward, and also a motto due to the late Colonel Kitson Clark, "Actorum memores simul affectamus agenda" ; freoly translated as "Mindful of what has been done, we strive at the same time after the things yet to be done". It was this idea that ran through some of the speeches at the dinner recently held, Dr. Dickinson urging the need for an influx of young and enthusiastic members to continue a work which is all the more necessary because its significance is not always appreciated.

The dinner had been preceded by the annual general meeting held at the Science Museum, when the twenty-fourth annual report of the Council and two papers were read. The report referred to the renewal of contacts with members abroad who had suffered under the Nazi tyranny, and to the forma. tion of a Midland branch with its headquarters in Birmingham. During the War, a few meetings had to be abandoned; but all the contributions as set down in the programmes had been received and their publication in the Transactions only awaits the release of printers and paper. After the passing of the accounts and the re-election of Mr. S. B. Hamilton as president for a second year, a paper followed by Mr. Greville Bathe, of the United States, on "The Onandaga Salt Works of the New York State, 16461846". This in turn was succeeded by a review of the work of the Society during the last quarter of a century by the president. The Society, he said, had striven to achieve its objects in many ways: by enlisting the help of individuals and institutions in preserving objects of historical value, by arousing interest in local industrial history by its summer meetings, by the researches of its own members and by the publication of memoirs, by collaboration with societies having somewhat similar aims, by the compilation of bibliographies and by other means. $\mathrm{H}_{\Theta}$ had classified the 358 papers contributed under the several headings of biography, ancient engineering, local industries, mills, mining, iron and steel, transport, tools, engines and the like, and he remarked that even if the Society were dissolved now, the twenty-one volumes of Transactions published, and the four held in suspense by inevitable delays, "are a unique contribution to historical literature". Many of the papers, he said, "are authoritative compilations by outstanding authorities who have made their respective fields peculiarly their own." As the Society has no house of its own, and meeting grounds were often chosen at places appropriate to the paper to be given, Mr. Hamilton concluded his review with an expression of thanks to the director of the Science Museum and to all those who had generously extended to the Society the use of their rooms for gatherings. In conclusion, it may be noted that besides Mr. Hamilton, the officers for the current year are Dr. H. W. Dickinson and Mr. A. Stowers, honorary joint secretaries, Mr. J. Foster Petree, honorary treasurer, with Miss G. Bingham, O.B.E., 43 King's Road, Chelsea, S.W.3, as assistant secretary.

\section{SCIENTIFIC RESEARCH IN INDIA AND THE BRITISH COLONIES}

$T$ THE first of a series of discussions on the organization of scientific research in the British Commonwealth, arranged by the Society for Visiting Scientists, was held at the Society's House at 5 Old Burlington Street, London, on December 5, with Prof. A. V. Hill in the chair. The speakers were: Dr. S. Siddiqui, director of the Chemical Laboratories C.S.I.R., Delhi ; Dr. J. L. Simonsen, director of the Colonial Products Research Council; Dr. E. B. Worthington, secretary of the Freshwater Biological Association, and author of the section on "Science in Africa" in Lord Hailey's "African Survey"; Major-General Sir John Taylor, late director of the Central Research Institute, Punjab. Those who took part in the subsequent discussion included: Dr. W. R. Aykroyd, director of the Nutrition Laboratories, Coonoor, Central India ; Sir Lewis Fermor, late director of the Geological Survey, India; Mr. C. Y. Carstairs, assistant secretary at the Colonial Office; Dr. C. H. Waddington, and Dr. C. Gordon.

Among the chief points made were the following : In India, government expenditure on research now amounts to the modest total of about $£ 200,000$ per annum, but the Council of Scientific and Industrial Research, which was founded in 1942, has drawn up a five-year plan for research, to be supervised by a proposed new National Research Council. The total expenditure under the plan would be $£ 4,500,000$, of which a considerable fraction would be found by industry. It would include grants for the training of a large number of urgently needed additional scientific personnel.

The outstanding results of scientific research in India to date have been in the field of tropical medicine. Here the Central Research Institute has similar functions to the Medical Research Council in Britain; through the Nutritional Advisory Committee, special consideration is given to nutritional problems. The Indian Geological Survey, established about a century ago, is expanding its activities, notably in relation to the discovery of now mineral resources and to the development of hydro-electricity.

Both in India and the Colonies, nutrition is of outstanding importance. However, it has been found that it cannot be tackled as an isolated research problem, but requires the study of many subjects, including water supply, soil erosion, malaria, agricultural science, land tenure, supply organization, demography and education.

In the course of the discussion, other examples emerged of problems which could only be properly tackled by this method of co-operating teams, often including students of both the natural and social sciences: for example, public health and water resources, the latter involving geology, soil-science, fisheries, meteorology, etc. The success of this method in operational research during the War was emphasized. Broad ecological research is increasingly necessary in tropical countries, and this too demands the co-operation of specialists from a number of fields.

In addition to the classical methods of research by subjects, and to this development of research and problems by wide teams, the method of research by 'sample areas' has recently been proved to be very effective. This was first tried in three different villages of Cyprus, one in the mountains, one in the foothills, one in the plains, where experts in medicine, 
forestry, agriculture and water supply are all cooperating. This method has also been used in the Colonies, and its general employment was discussed at the Quebec Conference on Food and Agriculture.

One point brought out during the discussion was the disparity now existing between wealthy and poor territories in regard to expenditure on science and its applications. Thus in Malaya, the expenditure on medical and health services is about 5s. a head of population, while in India, it varies from about $2 d$. to $1 s$. according to district.

The need for co-operation between scientific workers in the Dominions and the Colonies was stressed. Here the Empire Scientific Conference, which is to be held in 1946, holds out great promise.

Another need is for the raising of the status of the scientific worker in Colonial government service, so that he can occupy the same sort of position as a research worker in a good university at home. One way in which this could be achieved might be by having in each territory or regional group of territories a director of research, who would also be scientific adviser to the Government concerned, and to whom scientific workers in all fields should have direct access.

One of the most urgent problems in India and the Colonies is the study of industrial processes which can be utilized locally. Thus the conversion of molasses into industrial alcohol could be undertaken in sugargrowing countries, and the setting up of plants for extracting oil from oilseeds in Africa would provide large amounts of cattle food urgently required there. In this connexion, the decision to found a Microbiological Research Station in the West Indies is of great importance.

The discussion proved of great interest in focusing informed opinion on the urgent problems of research in India and the Colonies.

\section{SWEDEN'S WATER-POWER RESOURCES}

$\mathrm{D}$

URING the War, sixty new power stations were built in Sweden, several of more than $40,000 \mathrm{~kW}$. rating. The production of hydro-electric power in 1944 was 12,417 million $\mathrm{kWh}$., and water-power plants now total about $2,500,000 \mathrm{~kW}$. Further plants totalling about $600,000 \mathrm{~kW}$. will be completed towards 1950, and works have been started for an additional $350,000 \mathrm{~kW}$. The energy utilized in 1944 was 10,573 million $\mathrm{kWh}$., of which 4,428 million $\mathrm{kWh}$. were taken by the large industries for engine power, etc., while the electro-chemical and thermo-electric industries consumed 1,891 million $\mathrm{kWh}$. About 1,040 million $\mathrm{kWh}$. were used for traction purposes and 2,017 million $\mathrm{kWh}$. for domestic purposes, etc. 1,093 million $\mathrm{kWh}$. were used for electric steamgeneration at night-time and during non-working hours.

Plants built during the War cost about $£ 17,647,000$, and subsequent investments amount to about $£ 3,530,000$ a year.

During 1944, plant additions amounted to 280,000 $\mathrm{kW}$. Plants for a further $46,000 \mathrm{~kW}$. will probably be completed before the end of 1945. Among the new power-works to be completed within the next five years or so are those at Hjälta $(120,000 \mathrm{~kW}$.), Forsmoforsen $(75,000 \mathrm{~kW}$.), and Nämforsen $(46,000$ kW.), situated on the Angerman River with the tributary Fax River. One station of $46,000 \mathrm{~kW}$. will be built at Skedvi on the Dalälven River and one of $34,000 \mathrm{~kW}$. on the Ljusnan River.

A new station at the Harspranget waterfall in the Lule River will have a capacity of $250,000 \mathrm{~kW}$. The Suorva Dam at the Stora Lulevatten, the well-lake of the Lule River, has created a water storage with a maximum capacity of 113,000 million $\mathrm{cu}$. ft. and a regulating height of $191 \mathrm{ft}$. for the new station as well as for the existing Porjus plant.

The total Swedish water-power resources which can be exploited economically is estimated to correspond to about 36,000 million $\mathrm{kWh}$., of which one third has been utilized, while the second third is now being gradually taken into use. The last third will, however, be comparatively expensive to develop.

The networks of all the large power-plants are interconnected, and four heavy copper and steelaluminium transmission lines, stretching from the north of Sweden down through the whole country, constitute the arteries through which a large part of the country's electric energy is being supplied to industries, railways and households.

\section{NON-METALLIC DEPOSITS OF THE U.S.S.R.}

A NEW publication by the Academy of Sciences of the U.S.S.R., "Non-metallic Deposits of the U.S.S.R." (published in Russian), is planned on a large and comprehensive scale. Judging by the volume at hand (Vol. 2, 1943) this publication will extend over a number of volumes and greatly exceed a similar work published in four volumes during 1926-29, as the subjects discussed in the present volume cover 449 pages as compared with 96 pages of the previous edition. Volume 2 contains the following articles, each written by a specialist or a group of specialists on the given subject: (1) basalt and diabase, (2) barite and witherite, (3) beryl, (4) turquoise ("Biruza" in Russian), (5) bitumens and bitumenous rocks, and (6) bauxite. Each section comprises the following items: general description of the material and its mode of occurrence and genesis, localities where it is found, especially those in the U.S.S.R., methods of extraction and technology, economic statisties and bibliography.

The value of this work is manifold. First, because it gives a very full account of the localities and mode of occurrence of mineral deposits, especially those found in the Soviet Union, secondly because it provides new and interesting interpretations of data, classification, genesis and novel industrial uses. Such, for example, is the article by A. S. Ginsberg on basalt and diabase (dolerite), rocks which are extremely abundant in Britain and used mainly for road-metal, while in the Soviet Union, at the present time, they are also used for manufacturing electrical insulators, acid-resisting tanks and many other articles of industrial value, in the form of the so-called 'cast basalt'. The section on bitumens, written by a group of specialists, is of exceptional interest, especially the part written by V.A. Uspensky on the genesis and genetic classification of bitumens and also that written by A. P. Vinogradov on the occurrence of certain chemical elements, such as vanadium, nickel and uranium, in bitumens. Sections describing the occurrences of bitumens in the U.S.S.R. and the technology of bituminous products are also very interesting. The prospecting for bauxitic ores in the 